\title{
APPLICATION OF CONSTRUCTIVISM-BASED STUDENTS' WORKSHEET TO INCREASE STUDENTS ACTIVITIES AND LEARNING OUTCOMES
}

\author{
Susilawati $^{1^{*}, J_{i m m i} \text { Copriady }}{ }^{1}$, Maria Erna ${ }^{1}$, Hasnah $^{1}$, Rendra $^{1}$, Nurul Aulia Nisa ${ }^{1}$ and \\ Okma Rahmatya ${ }^{1}$ \\ ${ }^{1}$ Department of Chemistry Education, Faculty of Teacher Training and Education, Universitas \\ Riau, Kampus Binawidya Km. 12,5 Panam, Pekanbaru, 28293, Indonesia \\ ${ }^{*}$ E-mail: susilawati@lecturer.unri.ac.id
}

Received: 22 October 2019; Accepted: 04 February 2020; Published: 30 June 2020

\begin{abstract}
Information gained from lecturers of organic chemistry study program in chemical education Riau University, student activities and learning outcomes are still relatively low. The researchers believe that contructivism based students' worksheet as a new learning method is needed to overcome the problem. The study was conducted using the application of contructivism-based students worksheet in organic chemistry II subject to increase students activities and their learning outcomes. The data were collected by observation and test. Statistics descriptive qualitative and quantitative were used to analyze the data. The data of learning outcomes were analyzed by Shapiro- Wilks normality, Wilcoxon hypothesis test and paired samples test. The result showed that average values of student activity for each subject namely aldehyde-ketones, carboxylic acids, amines and free radicals were at 37\%,37\%,30\%,36\%. The result from wilcoxon and paired samples test, with significant test $0,000<0,05$ showed that student learning outcomes on organic chemistry II subject by constructivism-based students' worksheet was improved, It can be seen from average value of the pre-test and post-test were at $19.77 ; 72.15$, respectively.
\end{abstract}

Keywords: student worksheets, constructivism, learning activities, learning outcomes, organic chemistry II

DOI: https://doi.org/10.15575/jtk.v5i1.5607

\section{INTRODUCTION}

A branch of chemistry that discusses about the nature, structure, composition, reaction and synthesis of organic compounds is called organic chemistry. Many literatures have revealed the difficulty in identifying organic chemical compounds. According to Johston (in O'Dwyer et al. 2017), organic chemistry is a science and is difficult to understand. In previous works, it stated that the difficulties in organic subject are describing and representing organic compounds, isomers, properties of organic compounds, types of reaction and reaction mechanisms. Based on this review, it known that organic chemistry is exactly confirmed to be a difficult subject.

Information from the lecturers of organic chemistry at the Department of Chemical 
Susilawati, J. Copriady, M. Erna, Hasnah, Rendra, N. A. Nisa \& O. Rahmatya

Education, FKIP, Universitas Riau found that the learning activities and results were still relatively low. Data on the results of the organic chemistry exam last three years (2016) was $23.4 \%$, including the low category, all though the lecturers have given teaching subject in the form of student worksheets (SWs). SWs are teaching subjects designed to facilitate students to understand the subject in the learning process. Moreover, lecturers have facilitated the students by providing SWs in teaching and learning process, but the given SWs have not adopted an appropriate curriculum and not been affective in guiding students in understanding the subjects. Consequently, in the learning process students were not active and did not understand the subject, it made the activity and learning outcomes of students were obtained low.

Therefore, an innovation is sincerely needed to make organic chemistry courses easier to be learnt. To overcome this problem, teaching subjects are well required to increase enthusiasm and change difficult subject to be more easily understood. This opinion supported by Belawati (in Wirda et al., 2018), that teaching subjects are very important for lecturers and students in the lecture process. Meanwhile, without teaching subjects, the lecturers and students will find difficulties in increasing the effectiveness of learning and adjusting to learning (Arikunto in Wirda et al., 2018). One of the teaching subjects expected to improve the learning process is student worksheets based on constructivism.

SWs are teaching subjects to help students and contain guidance on learning activities. It is a tool to convey messages to the students in learning process and can be used to improve student effectiveness of student learning (Sasono, 2013). Kaymakci (in Yuliandriati et al., 2019) stated that "worksheet is one of the most important subjects for achieving the
Application of Constructivism-Based Students' Worksheet to Increase Students Activities and Learning Outcomes

goals of educational activities". This statement shows that SWs is one of the most important teaching subjects for achieving the objectives of educational activities.

Constructivism theory is a learning theory that can build knowledge from experience (Bhattacharjee, 2015). Constructivism learning develops thinking, where students will learn more meaningfully by working alone, discovering themselves, and constructing knowledge, so the knowledge is gained by students comes from the results of interpretations of experiences arranged in his mind. Then, students' knowledge is not derived from the subject given by the lecturers, but it originates from the results of their own business learned from their environment. The application of constructivism in learning toward students can be expected to answer concerns about future education outcomes. At least the students have an academic mentality, independence, optimistic future orientation, and are able to compete in the era of globalization (Hartono, 2011). In the constructivism approach, the learning is a process in forming knowledge and student must actively carry out activities, actively think, form concepts, and given meaning to thing learned, while lecturers are facilitators to provide optimal opportunities for learning.

Horsley (in Abidin, 2010) proposes that there are four stages in developing SWs based constructivism including 1) apperception stage (expressing initial conception and motivation to learn), 2) exploration stage (investigate and find concepts through collecting, organizing, and interpreting data), 3) stages of concept discussion and explanation (discussion and finding solutions obtained from the results of observations), 4) stages of concept development and 
Susilawati, J. Copriady, M. Erna, Hasnah, Rendra, N. A. Nisa \& O. Rahmatya

application (applying concepts that have been obtained).

The development of SWs have been performed by previous researchers and applied various research model including Febriani (2016) has reported research entitled utilization of student worksheets to increase student activity. The research based on Lesson Study in Indonesian Language Lessons. The results of this research found that the use of SWs could increase student activity in $71 \%$, $79 \%, 86 \%$, and $89 \%$ from the first cycle, second cycle, third cycle and fourth cycle, respectively. Suryani (2015) has also proposed the development of SWT-based on discovery in calculus courses and the results of research have obtained by increasing the activities and student learning outcomes during lectures.

Orbanić et al. (2016) have developed a constructivism learning model in photosynthetic subjects and obtained better learning outcomes. Another research has been conducted by Nurhasanah (2012) which focused on the development of student activity in courses of planning and development of mathematics through constructivism approaches in lesson study activities. The results of this study found that there was an increase in student activity during the learning process.

Constructivism learning improves the quality of knowledge acquired by students. The effectiveness of constructivist learning approaches in terms of knowledge gained from traditional approaches in the study of science teaching has also been developed by Tabago (2011). Furthermore, Amponsah and Ochnogor (2016) have conducted research to determine the effect of constructivism learning on the understanding of electrochemical concepts. The results of this study demonstrated that the use of the
Application of Constructivism-Based Students' Worksheet to Increase Students Activities and Learning Outcomes

constructivism approach could improve the understanding of students' electrochemical concepts. Muttakin (2017) has developed research about the development of SWsbased on multi-concepts on elementary chemistry courses. The result of this study found that there was an increase in students' understanding on learning elemental chemical concepts.

Based on the previous researches it is known that there has been no research conducted regarding the application of SWs based on constructivism to improve student learning activities and outcomes in organic chemistry courses. Based on the background, the purpose of this study is to increase the activity and learning outcomes of Chemistry Education study programs at the Faculty of Teacher Training and Education, Universitas Riau, Pekanbaru by using the institute of SWs based on constructivism in organic chemistry II.

\section{RESEARCH METHOD}

This research was conducted on student of semester IV at Study Program of Chemistry Education, Riau University in February - May 2018.

In this research, the data were collected by observation and test. The data were analyzed using descriptive qualitative and quantitative, and tested using software of SPSS 23.0. The data of learning outcomes were evaluated by using normality of Shapiro-Wilk, where the normality test was analyzed to determine the normal distribution of data. If the obtained data was normal distribution, then the parametric statistical test was performed. The testing data of Shapiro-Wilk normality is often used for sample size $\leq 50$ with a significance level of $5 \%$ or 0.05 . The criteria are $\mathrm{H}_{\circ}=$ data is normally distributed, $\mathrm{H}_{1}=$ data is not 
Susilawati, J. Copriady, M. Erna, Hasnah, Rendra, N. A. Nisa \& O. Rahmatya

normally distributed, $\mathrm{H}_{\circ}$ is accepted if sig $\geq$ 0,05 and $H_{\circ}$ is rejected if sig $<0,05$ and formulation used to calculate normality is shown in equation 1 .

$$
x^{2}=\sum_{i=1}^{k} \frac{\left(O_{i}-E_{i}\right)^{2}}{E_{i}}(1)
$$

Where, $X^{2}$ is value of chi-square, $O_{i}$ is observation value, $E_{i}$ is expectation value, area of class interval based on normal table multiplied by $N$ (total frequency) (pi $x N$ ) and $\mathrm{N}$ is number of data (total frequency). If the normality value is above 0.05 , then the data distribution is declared normal, and if the value is below 0.05, then it is interpreted as abnormal. The distributed data of normal is continued by parametric test, namely paired $\mathrm{t}$ test. Paired t-test is a statistical test that compares the average of two groups in pairs (Sugiyono, 2010). In this work, the used data were pre-test and post-test data. Paired sample t-test can be calculated using the equation 2.

$$
\begin{gathered}
t=\frac{\bar{d}}{\left(\frac{S D d}{\sqrt{N}}\right)} \text { whereas } \bar{d}=\frac{\sum d}{N}(2) \\
d=x_{1}-x_{2}
\end{gathered}
$$

Where, $\mathrm{t}$ is value of $\mathrm{t}$ count, $\bar{d}$ is average value of samples, SDd is value of standard deviation and $\mathrm{N}$ is number of samples. The significance level is $5 \%$ or $\alpha=0.05$. The obtained decision to accept or reject $\mathrm{Ho}$ in the test based on the
Application of Constructivism-Based Students' Worksheet to Increase Students Activities and Learning Outcomes

t-test is as follows: $\mathrm{H}_{\mathrm{o}}$ is rejected if sign $<0.05$ and $H_{\circ}$ is accepted if sig $>0.05$. If the data are not normally distributed, then the analysis is continued using nonparametric testing and analyzed utilizing the wilcoxon hypothesis. wilcoxon hypothesis is always utilized for nonparametric testing to evaluate differences between two groups of data with scale of ordinal and interval, but the data are not normally distributed. Wilcoxon testing is analyzed through a significance level of $5 \%$ or $\alpha=0.05$. The criteria for analysis are; Ho rejected if the value of asymptotic significance (2-tailed) $<0.05$ and Ho accepted if the value of asymptotic significance (2-tailed) $>0.05$ (Dahlan, 2011).

\section{RESULT AND DISCUSSION}

\subsection{Learning Activity}

Learning activities were observed and assessed by four observers. Observations were performed from beginning to the end of the learning process. This was conducted at every meeting. The result of observations from the student learning activities was summarized in Table 1. The observations were made on seven aspects which were adjusted to the constructivism learning model. Where, aspects of number, 1, 2, 3, 4, 6 and 7 were oral activities. While number five was a writing activity.

Table 1. Learning Activities used Constructivism-based SWs on Subject of Aldehyde-ketones

\begin{tabular}{|l|c|c|c|c|}
\hline \multicolumn{1}{|c|}{ Indicators } & \multicolumn{3}{c|}{ Student Activities } \\
\cline { 2 - 5 } & Meeting 1 & Meeting 2 & Meeting 3 & Average \\
\hline 1. Asking questions & $16 \%$ & $11 \%$ & $18 \%$ & $15 \%$ \\
\hline 2. Answering questions & $11 \%$ & $24 \%$ & $13 \%$ & $16 \%$ \\
\hline 3. Expressing opinions & $24 \%$ & $11 \%$ & $5 \%$ & $13 \%$ \\
\hline 4. Working together in discussions & $100 \%$ & $100 \%$ & $100 \%$ & $100 \%$ \\
\hline $\begin{array}{l}\text { 5. Working on development questions and } \\
\text { application of concept on constructivism- } \\
\text { based SWs }\end{array}$ & $100 \%$ & $100 \%$ & $100 \%$ & $100 \%$ \\
\hline $\begin{array}{l}\text { 6. Presentation of results for constructivism- } \\
\text { based SWs }\end{array}$ & $8 \%$ & $11 \%$ & $13 \%$ & $8 \%$ \\
\hline
\end{tabular}




\begin{tabular}{|c|c|c|c|c|}
\hline \multirow{2}{*}{ Indicators } & \multicolumn{4}{|c|}{ Student Activities } \\
\hline & Meeting 1 & Meeting 2 & Meeting 3 & Average \\
\hline 7. Summarizing lecture Subject & $3 \%$ & $5 \%$ & $5 \%$ & $4 \%$ \\
\hline \multicolumn{4}{|c|}{ Total } & $37 \%$ \\
\hline
\end{tabular}

Table 2. Student Learning Activities Found from The Developed Constructivism-based SWs through Subject of Carboxylic Acids

\begin{tabular}{|l|c|c|c|c|}
\hline \multirow{2}{*}{ Indicators } & \multicolumn{4}{c|}{ Student Activities } \\
\cline { 2 - 5 } & Meeting 1 & Meeting 2 & Meeting 3 & Average \\
\hline 1. Asking questions & $18 \%$ & $8 \%$ & $15 \%$ & $14 \%$ \\
\hline 2. Answering questions & $13 \%$ & $24 \%$ & $13 \%$ & $17 \%$ \\
\hline 3. Expressing opinions & $28 \%$ & $14 \%$ & $5 \%$ & $16 \%$ \\
\hline 4. Working together in discussions & $100 \%$ & $100 \%$ & $100 \%$ & $100 \%$ \\
\hline $\begin{array}{l}\text { 5. Working on development questions and } \\
\text { application of concept on constructivism- } \\
\text { based SWs }\end{array}$ & $100 \%$ & $100 \%$ & $100 \%$ & $100 \%$ \\
\hline $\begin{array}{l}\text { 6. } \\
\text { Presentation of results for SWs-based on } \\
\text { constructivism }\end{array}$ & $8 \%$ & $11 \%$ & $10 \%$ & $10 \%$ \\
\hline 7. Summarizing lecture Subject & $5 \%$ & $5 \%$ & $5 \%$ & $5 \%$ \\
\hline \multicolumn{1}{|c|}{ Total } & & & $\mathbf{3 7 \%}$ \\
\hline
\end{tabular}

Table 3. Student Learning Activities Utilized Constructivism-based SWs Via Subject of Amines

\begin{tabular}{|l|c|c|c|c|}
\hline \multirow{2}{*}{ Indicators } & \multicolumn{4}{c|}{ Student Activities } \\
\cline { 2 - 5 } & Meeting 1 & Meeting 2 & Meeting 3 & Average \\
\hline 1. Asking questions & $5 \%$ & $5 \%$ & $6 \%$ & $5 \%$ \\
\hline 2. Answering questions & $7 \%$ & $11 \%$ & $5 \%$ & $8 \%$ \\
\hline 3. Expressing opinions & $5 \%$ & $5 \%$ & $5 \%$ & $5 \%$ \\
\hline 4. Working together in discussions & $51 \%$ & $57 \%$ & $87 \%$ & $65 \%$ \\
\hline $\begin{array}{l}\text { 5. Working on development questions and } \\
\text { application of concept on constructivism- } \\
\text { based SWs }\end{array}$ & $60 \%$ & $39 \%$ & $88 \%$ & $62 \%$ \\
\hline $\begin{array}{l}\text { 6. Presentation of results for SWs-based on } \\
\text { constructivism }\end{array}$ & $27 \%$ & $15 \%$ & $21 \%$ & $63 \%$ \\
\hline 7. Summarizing lecture Subject & $5 \%$ & $4 \%$ & $5 \%$ & $5 \%$ \\
\hline \multicolumn{2}{|c|}{ Total } \\
\hline
\end{tabular}

Table 4. Student Learning Activities Obtained from The Proposed Constructivism-based SWs through Subject of Free Radicals

\begin{tabular}{|l|c|c|c|c|}
\hline \multirow{2}{*}{ Indicators } & \multicolumn{4}{c|}{ Student Activities } \\
\cline { 2 - 5 } & Meeting 1 & Meeting 2 & Meeting 3 & Average \\
\hline 1. Asking questions & $8 \%$ & $10 \%$ & $8 \%$ & $9 \%$ \\
\hline 2. Answering questions & $5 \%$ & $8 \%$ & $10 \%$ & $8 \%$ \\
\hline 3. Expressing opinions & $5 \%$ & $8 \%$ & $5 \%$ & $6 \%$ \\
\hline 4. Work together in discussions & $100 \%$ & $100 \%$ & $100 \%$ & $100 \%$ \\
\hline
\end{tabular}




\begin{tabular}{|l|c|c|c|c|}
\hline \multicolumn{1}{|c|}{ Indicators } & \multicolumn{3}{c|}{ Student Activities } \\
\cline { 2 - 5 } & Meeting 1 & Meeting 2 & Meeting 3 & Average \\
\hline $\begin{array}{l}\text { 5. Work on development questions and } \\
\text { application of concept on constructivism-based } \\
\text { SWs }\end{array}$ & $100 \%$ & $100 \%$ & $100 \%$ & $100 \%$ \\
\hline $\begin{array}{l}\text { S. Presentation of results for constructivism-based } \\
\text { SWs }\end{array}$ & $13 \%$ & $25 \%$ & $25 \%$ & $21 \%$ \\
\hline 7. Summarizing lecture Subject & $5 \%$ & $5 \%$ & $5 \%$ & $5 \%$ \\
\hline \multicolumn{2}{|c|}{ Total } \\
\hline
\end{tabular}

Table 5. Values of Student Learning Activities Obtained in Organic Chemistry II

\begin{tabular}{|l|c|c|c|c|c|}
\hline \multirow{2}{*}{\multicolumn{1}{|c|}{ Indicators }} & \multicolumn{5}{c|}{ Student activities } \\
\cline { 2 - 6 } & $\begin{array}{c}\text { Aldehyde- } \\
\text { ketones }\end{array}$ & $\begin{array}{c}\text { Carboxylic } \\
\text { acids }\end{array}$ & Amines & $\begin{array}{c}\text { Free } \\
\text { radicals }\end{array}$ & Average \\
\hline 1. Asking questions & $15 \%$ & $14 \%$ & $5 \%$ & $8 \%$ & $10 \%$ \\
\hline 2. Answering questions & $16 \%$ & $17 \%$ & $8 \%$ & $8 \%$ & $12 \%$ \\
\hline 3. Expressing opinions & $13 \%$ & $15 \%$ & $5 \%$ & $9 \%$ & $11 \%$ \\
\hline 4. Work together in discussions & $100 \%$ & $100 \%$ & $65 \%$ & $100 \%$ & $91,2 \%$ \\
\hline $\begin{array}{l}\text { 5. Work on development questions } \\
\text { and application of concept on } \\
\text { constructivism-based SWs }\end{array}$ & $100 \%$ & $100 \%$ & $62 \%$ & $100 \%$ & $90,5 \%$ \\
\hline $\begin{array}{l}\text { 6. Presentation of results for } \\
\text { constructivism-based SWs }\end{array}$ & $8 \%$ & $10 \%$ & $21 \%$ & $21 \%$ & $25 \%$ \\
\hline 7. Summarizing lecture Subject & $4 \%$ & $5 \%$ & $5 \%$ & $5 \%$ & $5 \%$ \\
\hline \multicolumn{1}{|c|}{ Average of activities } & $\mathbf{3 7 \%}$ & $\mathbf{3 7 \%}$ & $\mathbf{3 0 \%}$ & $\mathbf{3 6 \%}$ & $\mathbf{3 5 \%}$ \\
\hline
\end{tabular}

Generally, the average values of student learning activities for subject of aldehydeketones, carboxylic acids, amines and free radicals were at $37 \%, 37 \%, 30 \%$, and $36 \%$, respectively. Explanations for each learning activities observed were as follows ;

\subsubsection{Asking Questions}

Asking question was performed by lecturer to encourage, guide and assess students' thinking skills. Through asking question obtained information and confirm something is known and directed attention to aspects that are not yet known. Student activities are obtained quite well in asking question. This is indicated by existence of student who ask in each meeting with an average question of 10 $\%$. The question was started when the lecturer conveys motivation, explanation of subject, working on SWs, presentation and reflection activities.

\subsubsection{Answering Question}

Each meeting was actively demonstrated student in answering question with an average score of $12 \%$. It contributed that the lecturer was not directly answered the students' questions, but it was provided an opportunity for other students to answer.

\subsubsection{Expressing Opinions}

The students who were active in expressing opinions could be seen from each meeting and obtained an average value of $11 \%$. It happened because the students were given the opportunity by the lecturer to answer questions and producted an opinions from other students about the answer of his friend. 
Susilawati, J. Copriady, M. Erna, Hasnah, Rendra, N. A. Nisa \& O. Rahmatya

In expressing opinion, the student could work in group and performed division of task in the learning process. This could stimulate student to argue and express opinions, consequently the student actively participate in the learning process. The activities in expressing opinions found the lowest value in amine subject of 5 $\%$. This caused by the opportunity and time available were not enough for students to give a response.

\subsubsection{Collaboration in Discussion}

Discussion is a process of exchanging information, opinions, and experiences in order to get a clearer and more accurate explanation of the problems being discussed. At the time of working on SWs, the cooperation was not dominated by smart students. The discussion was conducted by all students in the group and asked the lecturer, if there was a mistake. The activity of working on SWs obtained a value of $91.25 \%$, this was contributed by the desire of student to understand the subject well. The lecturer has guided and directed student to work individually on SWs and then discussed with group members. The answers were written on sheet of SWs, this could increase student memory of the subject being studied. Students who understood and memorized subject could help other student not understand the subject.

\subsubsection{Work on Development Questions and Application of Concept on SWs- based on Constructivism}

The value of activity in working questions and application of concept in SWs was procured at $90.50 \%$. This value was as large as the value obtained in discussion activities. This value supported by Suryani (2015) about the activity of working on SWs which was also obtained a high percentage value. This was contributed by constructivism-based SWs given stages such as exploration, discussion, explanation of concept, development and application of
Application of Constructivism-Based Students' Worksheet to Increase Students Activities and Learning Outcomes

concepts to make enthusiastic students to read and solve questions on the SWs. At the explanation stage, the investigation and discovery of concepts were performed by students through collection and interpretation data. Whereas, the stage of discussion and explanation were conducted to solve problems obtained from observation. Meanwhile, the stages of development and application were applied conceptual understanding obtained by solving a problem in the form of question contained in the SWs. During completing the question, the students were given division of task and the obtained results were discussed again to examine the truth of the answer made.

\subsubsection{Presentation of Results for SWs- based on Constructivism}

Working together in a discussion made students understand the subject well. The student could be explained the results of discussion well, it was contributed that in the discussions there were no dominant students. The average value of student activities in the presentation was $25 \%$. This value was caused by student who present at each meeting differently.

\subsubsection{Conclusion of Lecture Subject}

The learning process using constructivismbased SWs could make students to construct their knowledge. The learning process was more meaningful, where students learn through the stages of constructivism which starts from reading to drawing conclusions about the lessons. The indicator of student activity concluded that the lecture subject has the lowest average value compared to other indicators which was $5 \%$. This means that not a few conclude subject, but the delivered conclusions were in accordance with the subject provided, so that the other students not to point their hands again. Other indicators found low percentage average 
Susilawati, J. Copriady, M. Erna, Hasnah, Rendra, N. A. Nisa \& O. Rahmatya

values such as asking questions, answering questions, and expressing opinions were at $10 \%, 12 \%, 11 \%$, respectively. The low value of this indicator was contributed because the opportunity and time available were insufficient for students to ask questions. The same thing was experienced in expressing opinions, if the answers given by the group that made the presentation were justified; there was not much that needs to be addressed.

Student activities in the learning process were very necessary to construct their knowledge. Preliminary knowledge would increase with the learning process using SWs-based constructivism. The process of discussion of students with colleagues would make students more quickly understand the subject available.
Application of Constructivism-Based Students' Worksheet to Increase Students Activities and Learning Outcomes

The average activity of students from meeting each subject did not show improvement. This was caused by subject characteristics of quite complex. This is supported by Nurhasanah (2012) who reported on the development of student activeness in the learning process of mathematics courses through constructivism approach in lesson study activities.

\subsection{Learning Outcomes}

The assessment of learning outcomes was performed by looking at student learning outcomes. The performed assessment has applied constructivism-based SWs on subject of organic chemistry II. The data used in the assessment came from the values of pre-test and post-test. The value of the student's pretest-post-test could be shown in Table 6 .

Table 6. The Values of Learning Outcomes Obtained from The Average Pre-test and Post-test on Subject of Organic Chemistry II

\begin{tabular}{|c|c|c|c|}
\hline \multirow{2}{*}{ No } & \multirow{2}{*}{ Subject } & \multicolumn{2}{|c|}{ Values of Pre-test dan Post-test } \\
\cline { 3 - 4 } & & Pre-test & Post-test \\
\hline 1. & Aldehyde-Ketone & 23,24 & 88,37 \\
\hline 2. & Carboxylic acid & 15,61 & 62,33 \\
\hline 3. & Amine & 24,65 & 74,43 \\
\hline 4. & Free radical & 15,57 & 63,88 \\
\hline \multicolumn{2}{r}{} & $\mathbf{1 9 , 7 7}$ & $\mathbf{7 2 , 2 5}$ \\
\hline
\end{tabular}

Table 7. Results for The Normality of Shapiro-Wilk and Testing Hypothesis Procured from The Subject of Aldehyde-ketones, Carboxylic Acids, Amines and Free Radicals

\begin{tabular}{|c|c|c|c|c|c|c|}
\hline & & & Aldehyde-Ketones & Carboxylic acids & Amines & Free radicals \\
\hline \multirow[t]{3}{*}{1} & \multirow{2}{*}{$\begin{array}{c}\text { Testing } \\
\text { Shapiro- } \\
\text { Wilk (Sig) }\end{array}$} & $\begin{array}{l}\text { Pre- } \\
\text { test }\end{array}$ & $0,019<0,05$ & $0,082>0,05$ & $0,027<0,05$ & $0,179>0,05$ \\
\hline & & $\begin{array}{c}\text { Post- } \\
\text { test }\end{array}$ & $0,001<0,05$ & $0,234>0,05$ & $0,011<0,05$ & $0,435>0,05$ \\
\hline & \multicolumn{2}{|c|}{ Conclusions } & $\begin{array}{l}\text { Not normal } \\
\text { distribution }\end{array}$ & Normal distribution & $\begin{array}{l}\text { Not normal } \\
\text { distribution }\end{array}$ & Normal distribution \\
\hline \multirow{3}{*}{2} & \multicolumn{2}{|c|}{ Testing Hipotesis } & Wilcoxon & Paired Samples Test & Wilcoxon & Paired Samples Test \\
\hline & \multicolumn{2}{|c|}{ Significant values } & $0,000<0,05$ & $0,000<0,05$ & $0,000<0,05$ & $0,000<0,05$ \\
\hline & \multicolumn{2}{|c|}{ Conclusions } & $\begin{array}{l}\text { There were significant } \\
\text { differences between } \\
\text { the values of pre-test } \\
\text { and post-test }\end{array}$ & $\begin{array}{c}\text { There were } \\
\text { significant } \\
\text { differences between } \\
\text { the values of pre- } \\
\text { test and post-test }\end{array}$ & $\begin{array}{c}\text { There were } \\
\text { significant } \\
\text { differences between } \\
\text { the values of pre- } \\
\text { test and post-test }\end{array}$ & $\begin{array}{c}\text { There were } \\
\text { significant } \\
\text { differences between } \\
\text { the values of pre- } \\
\text { test and post-test }\end{array}$ \\
\hline
\end{tabular}


Susilawati, J. Copriady, M. Erna, Hasnah, Rendra, N. A. Nisa \& O. Rahmatya

Based on Table 7, data was normally distributed if the significant value obtained $\geq$ 0,05 and the data were not normally distributed if the significant value found < 0.05. Testing hypothesis for normally distributed data was utilized the paired samples test. Meanwhile, testing hypothesis for the not normally distributed was used the Wilcoxon test. The data for subject of aldehyde-ketones and amines were not normally distributed with significant values < 0.05 . Therefore, the testing hypothesis utilized Wilcoxon test. Whereas, the subjects of carboxylic acids and free radicals were normally distributed with a significant value of $>0.05$ dan used testing paired samples test. In the meantime, the significant value for all hypothesis testing from subject of organic chemistry was found to be $0.000<0.05$. It concluded that there were significant differences between the values of pre-test
Application of Constructivism-Based Students' Worksheet to Increase Students Activities and Learning Outcomes

and post-test. This demonstrated that the application of Constructivism-based SWs on subject of aldehyde-ketones, carboxylic acids, amines, and free radicals could improve the student learning outcomes.

The learning process was applied in the use of constructivism-based SWs. Before treatment, the pre-test was given to determine the students' initial abilities. Then it was continued by applying SWs-based constructivism on subject of organic chemistry II. The results showed that the application of constructivismbased SWs could improve student learning outcomes. The results of this study supported by Armis (2013) and Setiawan et al. (2016) who suggested that the approaches of constructivism could improve the student learning outcomes. The graph student learning outcomes was described in Figure 1.

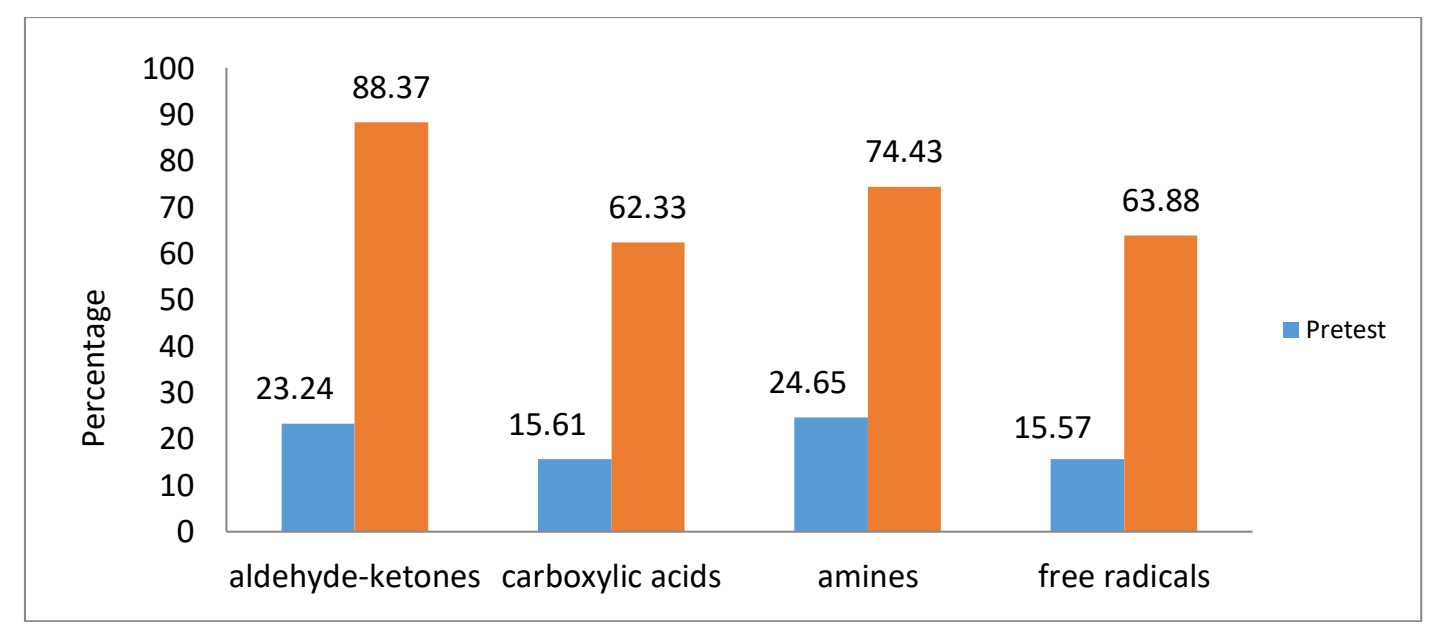

Figure 1. The Pre-test and Post-test Values of Student Obtained from Subject of Aldehyde-ketone, Carboxylic Acids, Amines and Free Radicals

Figure 1 demonstrated an increasing value of the student pre-test-post-test in each subject. This caused by the learning process of constructivism-based SWs including stage of apperception, exploration, discussion and explanation of concepts, development and application of concepts could be applied properly. This stage of learning was performed at each meeting. The stages of apperception were conducted at the beginning of learning to stimulate and provide questions about phenomena related to the subject discussed.

The stage of exploration was needed to find out concepts through data collection, organization and data interpretation in an 
Susilawati, J. Copriady, M. Erna, Hasnah, Rendra, N. A. Nisa \& O. Rahmatya

activity designed by lecturer. In this stage, the students were given information about a concept that makes students thinking. Meanwhile, the exploration section was delivered information to the students about the subject discussed for each meeting. In this stage, the students were presented opportunity to discuss in their group to get good answers. The exploration section at the second meeting was presented subject about amines on the Ma Huang plant containing ephedrine. After the discourse in the exploration section was found questions related to the process of obtaining ephedrine, this question could be discussed by students as subject to increase their knowledge.

The next stage was a discussion and explanation of concepts that contains the subject discussed by the students. One of the subjects was discussed about physical properties of amines related to the boiling points. The boiling point of amine molecule is between the boiling point of alkane and alcohol. The weight of low amine molecules can be dissolved in water because it forms hydrogen bond with water. Primary, secondary and tertiary amines can form hydrogen bonds with water. However, tertiary amines in pure water cannot form hydrogen. The last stage was the development and application of concepts. This stage, the students were given questions to test concepts understanding of student toward the developed subject. The given subject was filled with questions and it could make student to develop and reapply the concepts obtained from the previous stage. The example form of question was "what were factors influence the boiling and solubility of amines?" This question was utilized to test students' understanding of physical properties of amine molecules.

According to the constructivism theory, the learning is a formation of knowledge
Application of Constructivism-Based Students' Worksheet to Increase Students Activities and Learning Outcomes

conducted by individuals who learn. The students are actively encouraged to perform activities, active thinking and develop concepts. Constructivism views that students are individuals who have initial ability to learn something new. In addition, it also sees learning activities as active activities for student to find something and built their knowledge and are not a mechanical process to collect facts. This is according to Bhattacharjee's opinion (2015) that constructivism theory is a learning theory that can build knowledge from experience.

Based on principles of constructivism learning the students are provided an opportunity to actively construct their own knowledge with the help of lecturer. The principle of this study is also given the opportunity for students to study independently. Constructivism-based SWsis one of teaching subject given for student to build their knowledge. SWs can be used to improve student effectiveness of student learning (Sasono, 2013). Constructivism learning is applied for student to produce good learning outcomes. This was strongly supported by research results that constructivism-based SWs could improve the student learning outcomes in subject of organic chemistry. The increasing could be seen from the value of pre-test of 19.77 and increased to be 72.25 for the value of posttest. Constructivism-based SWs is proper given to the student because it is in line with cognitive level of students in constructing knowledge.

\section{ACKNOWLEDGMENTS}

We would like to thank DRPM Ristek Dikti, and LPPM Riau University for funding assistance for this research in the form of Master Thesis Research Grand 2019. 
Susilawati, J. Copriady, M. Erna, Hasnah, Rendra, N. A. Nisa \& O. Rahmatya

\section{CONCLUSION}

The implementation of Constructivism-based SWs was confirmed by increasing activities of student learning. The average percentage of student activity in each subject such as aldehyde-ketones, carboxylic acids, amines, and free radicals were at $37 \%, 37 \%, 30 \%$, and $36 \%$, respectively. Although some activities were not improved as characteristics of complex subject and insufficient time available.

The application of constructivism-based SWs could increase learning outcomes of students in Department of Chemistry Education, The Faculty of Teacher Training and Education, Riau University on subject of organic chemistry II. The improved learning outcomes demonstrated in the pre-test and post-test values were 19.77 and 72.25 , respectively.
Application of Constructivism-Based Students' Worksheet to Increase Students Activities and Learning Outcomes 
Susilawati, J. Copriady, M. Erna, Hasnah, Rendra, N. A. Nisa \& O. Rahmatya

\section{REFERENCES}

Abidin, Y. (2010). Strategi Membaca Teori dan Pembelajarannya. Bandung: Rizki Press.

Amponsah, K. D. \& Ochonogor, C. E. (2016). Impact of a Constructivist Approach to Learning on High Achieving Students Comprehension of Electrochemistry concepts. The Eurasia Proceedings of Educational \& Social Sciences, 4, 220231.

Armis. (2013). Penerapan Pendekatan Konstruktivisme dalam Perkuliahan Perencanaan Pengajaran Matematika. Jurnal Edumatica, 3(1), 1-10.

Bhattacharjee, J. (2015). Constructivist Approach to Learning-An Effective Approach of Teaching Learning. International Research Journal of Interdisciplinary \& Multidisciplinary Studies, 1(4), 23-28.

Dahlan M.S. (2011). Statistik untuk Kedokteran dan Kesehatan Edisi 3. Jakarta: Salemba Medika.

Febriani, M. (2016). Pemanfaatan Lembar Kerja Mahasiswa untuk Meningkatkan Keaktifan Mahasiswa: Studi Penerapan Lesson Study pada mata kuliah Buku Teks Pelajaran Bahasa Indonesia. Jurnal Pendidikan Bahasa dan Sastra, 16(1), 203-212.

Hartono. (2011). Peningkatan Aktivitas dan Hasil Belajar Mahasiswa Program Studi Biologi Universitas Negeri Makassar (UNM) pada Mata Kuliah Ekologi Hewan Melalui Model Konstruktivisme. Jurnal Bionature, 12(1), 26-34.
Application of Constructivism-Based Students' Worksheet to Increase Students Activities and Learning Outcomes

Muttakin, M. (2017). Pengembangan Lembar Kerja Mahasiswa (LKM) yang Multikonsep pada Perkuliahan Konsep Kimia Unsur. Jurnal Edukasi Kimia (JEK), 2(1), 54-65.

Nurhasanah, F. (2012). Membangun Keaktifan Mahasiswa pada Proses Pembelajaran Mata Kuliah Perencanaan dan Pengembangan Program Pembelajaran Matematika melalui Pendekatan Konstruktivisme dalam Kegiatan Lesson Study. Jurnal Infinity, 1(1), 62-78.

O'Dwyer, A., \& Childs, P. E. (2017). Who Says Organic Chemistry is Difficult? Exploring Perspectives and Perceptions. EURASIA J. Math. Sci. Technol. Educ, 13, 3599-3620.

Orbanić, N. D., Dimec, D. S., \& Cencič, M. (2016). The Effectiveness of a Constructivist Teaching Model on Students'understanding of Photosynthesis. Journal of Baltic science education, 15(5).

Sasono, M. (2013). Pemanfaatan LKM dan Animasi Java Laboratory sebagai Media Pembelajaran Fisika pada Mata Kuliah Fisika Kuantum untuk Meningkatkan Aktivitas Belajar Mahasiswa Program Studi Pendidikan Fisika FPMIPA IKIP PGRI Madiun. Jurnal Edukasi Matematika dan Sains, 1(1). 3640.

Setiawan, M.A, Dasna, I.W., \& Marfu'ah, S. (2016). Pengaruh Bahan Ajar Multimedia terhadap Hasil Belajar dan Persepsi Mahasiswa pada Mata Kuliah Kimia Organik I. Jurnal Pendidikan, 1(4), 746-751. 
Susilawati, J. Copriady, M. Erna, Hasnah, Rendra, N. A. Nisa \& O. Rahmatya

Sugiyono. (2010). Statistika untuk Penelitian. Bandung: Alfabeta.

Suryani, M. (2015). Efektivitas Penggunaan Lembar Kerja Mahasiswa (LKM) berbasis Discovery pada Perkuliahan Kalkulus Peubah Banyak 1 (KPB 1) di STKIP PGRI Sumatera Barat. Jurnal Lemma, 7(2).

Tabago, L. C. (2011). Effectiveness of Constructivist Approach Experiments in Teaching Selected Physics Concepts. IAMURE: International Association of Multidisciplinary Research Journal Science and Technology Section, 2(1), 219-236.

Wirda, M.A, Rosni, Berutu. N., \& Rahmad, R. (2018). Pengembangan Lembar Kerja Mahasiswa (LKM) Berbasis Project pada Mata Kuliah Evaluasi Hasil Belajar Geografi TA 2017/2018. Jurnal Geografi, 10(2), 164-175.

Yuliandriati, Y., Susilawati, S., \& Rozalinda, R. (2019). Pengembangan Lembar Kerja Peserta Didik Berbasis Problem Based Learning pada Materi Ikatan Kimia Kelas X. JTK (Jurnal Tadris Kimiya), 4(1), 105-120.
Application of Constructivism-Based Students' Worksheet to Increase Students Activities and Learning Outcomes 